Accepted manuscript.

Citation Reference:

Carrascal Pérez, M.; González Martínez, P.; Memba Ikuga, L.; Muchada Suárez, A.; Rabasco Pozuelo, P.; Sendra Fernández, P. (2015) "Crossed Colonization. Housing Development in Urban Peripheries. The Hispanic-African Colonial Territories, 1912 - 1976 - 2013". In Nunes Siva, C. (Ed.) Urban Planning in Sub-Saharan Africa: colonial and postcolonial planning cultures. New York: Routledge, pp. 180-200. ISBN: 9780415632294.

\title{
Crossed Colonization. Housing Development in Urban Peripheries. The Hispanic-African Colonial Territories, $1912-1976-2013$
}

María Carrascal Pérez

Plácido González Martínez

Laida Memba Ikuga

Alejandro Muchada Suárez

Pablo Rabasco Pozuelo

Pablo Sendra Fernández

ABSTRACT

This chapter aims to fill a gap in the field of urban studies and colonialism in Africa regarding the processes of design and construction of public housing projects in Hispanic-African territories and their contextualization-at a global and a local scaleboth at the time of their construction and in their current situation. To do so, this chapter studies three different cases located in Morocco, Western Sahara and Sidi Ifni, as well as Equatorial Guinea. By analyzing these case studies, the chapter concludes with a reflection upon the relationship between colonialism, power, inequality and spatial transformation in these former Hispanic African territories.

Keywords: housing, periphery, Tetouan, Aaiun, Malabo, Spanish colonialism

\section{INTRODUCTION}

Housing inequalities in contemporary Africa are a consequence of the colonial action of European powers. Regarding contemporary African history, the changes that were implemented in local cultures during this period were the result of structural actions, and not the by-product of circumstances. 
Imported urban and architectural schemes and models have proven to be inadequate given local realities, needs and capabilities. That is why since the Colonial period, dissatisfaction with residential conditions and urban exclusion levels has been on the rise both in African cities and all over the continental territory. As a result, the creation of urban slums has been a historic process, and slums now amount to more than $30 \%$ of residential construction in countries such as Morocco (ZAKI, 2006).

Awareness has risen recently with respect to this phenomenon, and studying the relationship between colonialism and modernity implies going beyond the surface of the issue. This means that starting with a look at modern architecture in Africa, we can achieve a deeper understanding of the cultural consequences of the process of colonization.

We propose to have a direct insight on the specific matter of modern urbanism and housing that built the peripheries of African cities, as they were based on a variety of notions regarding land and real estate property; the symbolic use of land; the management of space and means of construction, as well as decision-making and social participation. Studying this form of production, we are able to check how this collided with the cosmography, values, and cultural and legal principles that had existed throughout the African territory, and which traditionally conformed the basis upon which the traditional habitats (kasbahs, medinas and dowares) were built.

Within this context, knowledge on Spanish colonization remains scarce, even in Spanish circles, compared to the last advancements coming from former colonial powers such as Portugal, Belgium and France. The countries subject of our research, the former Spanish colonies of Morocco, Western Sahara and Equatorial Guinea, have become part of global hyper capitalist processes, and due to their political "stability", are currently undergoing rapid economic growth. Processes which are similar to those happening in contemporary Africa that have their roots on the historical period of colonization.

This article analyses the production of social housing for the local population during colonization, using three significant case studies: the Mulay Hassan neighborhood (Tetouan, Morocco, 1955); the new city of El Aaiun (Western Sahara, 1962) and Los Ángeles neighborhood (Malabo, Equatorial Guinea, 1967). Each case follows a common structure, starting from a depiction of their colonial history: this shows the differences between the colonial programs that were implemented in each territory, trying to give an answer to their cultural, social and geographical specificity.

Each case study will be set within the context of their respective capital cities. This provides an insight into the ongoing dialectics between center and periphery, which vary on each case: from the consolidated historical condition of the "medina" in Tetouan to the newly built military settlement of El Aaiun, through the integration 
of public housing projects in the grid of the first settlement of Malabo. This is followed by a precise description of each project, revealing their attempts for specificity in the design of the housing units, the cultural references underneath modern urban design, as well as the relations established with the urban context.

Finally, this article concludes with a reflection on the contemporary situation. Field visits to the sites done by GAMUC reveal differences in the degree of appropriation of housing, as well as transformations in the urban landscape and the renovation of public infrastructures. Seen from a post-colonial perspective, the case studies show the perpetuation of a long-term process of exclusion, to which the new habitat still requires a negotiated and truly democratic response.

\section{HISPANIC AFRICAN COLONIZATION}

The study of the Spanish presence in Africa shows a whole variety of historical, administrative, geographical and cultural situations. It can be summarized as:

- Morocco: the colonial process begun during the last third of the $19^{\text {th }}$ Century, and was later formalized with the establishment of the Protectorate between 1912 and 1956 in the Northern part of the country. Spain shared Morocco with France, who kept the South.

- Western Sahara and Sidi Ifni: colonized during the last third of the 19th Century, but not effectively occupied until 1934. It became a Spanish province in 1958, two years after Moroccan independence, until its decolonization in 1976.

- Equatorial Guinea: colonized since $1777^{1}$, given its strategic importance as an outpost in the control of the slave trafficking routes to Europe and America. After a short period of British occupation, it was returned to Spain in 1843. Bioko and Rio Muni became autonomous Spanish provinces in 1963, until their declaration of Independence in 1968.

Due to the particularities of these three different territories, in order to illustrate the theme of this chapter we will follow a common structure for all three cases:

- First, we will give a brief general introduction to their colonial history,

- Second, we will offer a depiction of the changes carried out in each of the colonial capital cities,

- Third, we will show detailed insight into a selection of collective urban housing projects developed by the Spanish colonial authorities.

\section{MOROCCO: A SHARED HISTORY ACROSS THE STRAIT OF GIBRALTAR}

Manuel Azaña, the Spanish Prime Minister during the Second Spanish Republic (1931-1939), established that the role of Spain in Morocco was the following: the fulfilment of the international mandate on the Protectorate, which was established in 1912 through the Treaty of Fes; to provide a commercial, industrial and territorial 
expansion to the Spanish people; to offer an example of civilization to the Moroccan population (sic) (Salas, 1992).

Regarding this colonization process, there were pre-existing political conditions which Spain necessarily had to consider, such as the division of the local administration between the Bled Makhzen -territories controlled by the sultanate's hard power- and the Bled Shiba -territories controlled by the sultanate's soft power. This resulted in a complex organization. The geographical particularities of the country were also relevant: the West of the Spanish Protectorate was traditionally urban, while the Rif, the mountain region to the East of the territory, had a mere $5 \%$ of urban population in 1912, at best estimates (Laroui, 2001: 55; Villanova, 2006).

The history of the Spanish Protectorate is that of a mixture of cooperation and resistance by the local population. The first period, between 1912 and 1927, was characterized by an open state of war, especially in the Rif region, where the conflict caused deep concern at a national level. From 1927 to 1939, albeit the cessation of the open conflict, there reigned a period of instability, a mirror image of the political situation in Spain itself, which would become especially dramatic during the Spanish Civil War (1936-1939). The period between 1939 and 1956 was that of a relative stability characterized by state planning, as a reward for the support that Franco received from Africa during his uprising and the Spanish Civil War.

During the Spanish Protectorate period between 1912 and 1956, colonial investment policy was oriented towards three main areas: public works and infrastructures (64.92\% of the total budget); health (11.24\%), and education (10.68\%). Traditionally, Spanish colonial action in Morocco remained clearly behind the mighty colonial enterprise that France directed in its Protectorate in the South of the country. Not only the size of the administered territory, but also Spain's particular political status after World War II greatly influenced this situation.

\section{Tetouan as a capital city}

Differences between French and Spanish colonial action were immediately translated into the urban planning of Moroccan cities. National tendencies in urban design were reflected in urban development, as well as the relative cultural affinities between the colonizers and the local population. In Tetouan, the old Medina, with a population of 20.000, was expanded using the scheme of the "Ensanche", a regular grid inspired by the work of Ildefons Cerdá in Barcelona (Muchada, 2012b). The Spanish quarter of the Ensanche in Tetouan was planned in $1913^{2}$, showing the importance of the new role that public space had to play in the

\footnotetext{
2 España. Ministerio de Educación, Cultura y Deporte (MECD), Archivo General de la Administración (AGA), sección África, Caja 330, signatura Exp.3 81/3605-3608. Plano Negociado de Bienes Majzén. Proyecto de Ensanche. 1915MECD, AGA, sección África, signatura (15)032.002: Plano M-19. Carpeta 70, Mod. 81/Planero 4/Cajón 5. Plano reformado del ensanche de Tetuán. 1916. C. Ovilo.
} 
Protectorate. This was especially so in the Feddan Plaza, which played the part of the main transition space between the Medina, where most of the local population initially remained, and the new Spanish quarter.

This was a completely new and experimental situation, even if the model of the Ensanche had been put into practice in several Spanish cities during the late $19^{\text {th }}$ and beginning of the $20^{\text {th }}$ centuries. Ensanche-like operations had normally also entailed the sanitation of existing city centres. This was not the case in Tetouan, which remained relatively untouched. If we also compare contemporary urban expansion plans in the French Protectorate, the situation in Tetouan differed greatly due to:

- The role of the shared public space of the Feddan Plaza, which was that of a buffer zone and/or meeting point between the local people and the colonizers;

- The growing presence of Spanish immigration within the Medina after the first years of the Protectorate, which speaks of the mostly humble origins of the colonizers, as well as of the cultural and environmental affinities they shared with cities in the southern Spain;

- The limited means of the Spanish administration to implement the plan due to political instability and the lack of a solid legislative and economic framework.

The relevance of the experimental approach of Spanish colonial urbanism can also be observed through the work the renowned architect Pedro Muguruza. In 1943, he implemented in Tetouan the first ever modern Spanish General Urban Plan, a plan that even predates the approval of the Plan that urban planner Pedro Bidagor was preparing for Madrid-later approved in $1946 .{ }^{3}$ Muguruza's Plan was innovative in terms of implementing zoning laws, as well as by instituting the role of partial plans, which are the model tool for Spanish urban planning to date.

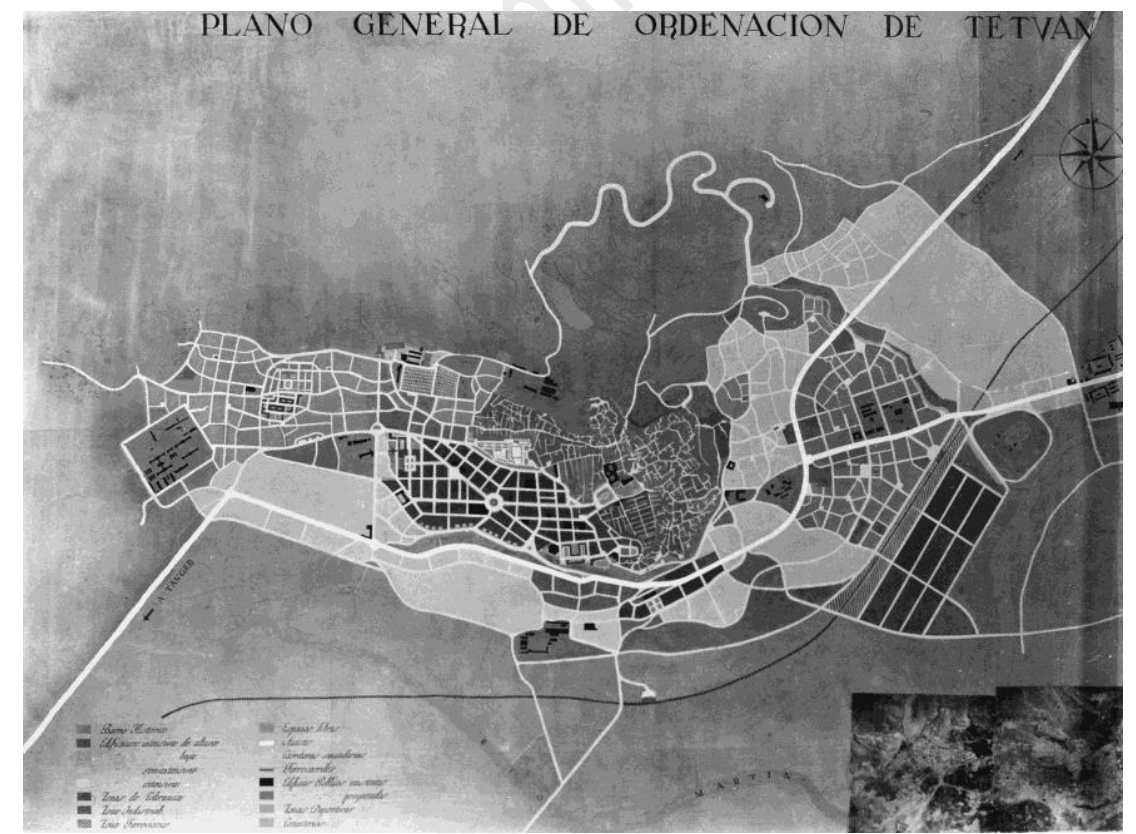

III. T1. Urban Plan of Tetouan, 1943.

\footnotetext{
3 Archivo Real Academia Bellas Artes San Fernando, Madrid. Signatura PL-4997-4999. Plan General de Ordenación de Tetuán. (1943). P. Muguruza.
} 
Source: Archivo de la Real Academia de Bellas Artes de San Fernando, Madrid. Fondo personal de Pedro Muguruza Otaño. Plan General de Ordenación Urbana de Tetuán, 1943.

Unfortunately, since it lacked financial and legal means, the Muguruza Plan steppedup the land speculation process that the Ensanche had already triggered. This eventually led to the informal city that is Tetouan's main feature today. Nevertheless, Spanish action on public housing meant a small percentage of the growth of the city during those years: from 1912 to 1956, the population of Tetouan rose from 20.000 to 120.000 inhabitants, while the Spanish government built a total of 1.500 housing units in the city (DE SIERRA, 1960b).

\section{Mulay Hassan, a model modern neighbourhood}

Mulay Hassan was the last large scale public housing development to be carried out by the Spanish government in Tetouan. Located on the East side of the city, it proved to be insufficient given the unstoppable growth of the population. Nevertheless, it was a big propaganda achievement, completed only three years before the end of the Protectorate. Alfonso de Sierra Ochoa was the author of the project, a renowned architect during the colonial period as well as the only Spanish theoretician and expert in traditional housing in the region. His work "La vivienda marroquí, notas para una teoría", published in 1960, is still considered a fundamental source on the subject of asserting the need of an empathic approach to the themes of housing and urban planning.

This is why Mulay Hassan is considered the most advanced approach to a cultural understanding of the local habitat, even if its achievements were still very modest (Muchada, 2012a). The layout of this development consisted of three housing slabs and single family houses, comprising a total of 400 housing units. The housing slabs followed a corridor scheme, on which different versions of the apartments (for Moroccan and Spanish families) could be built. 

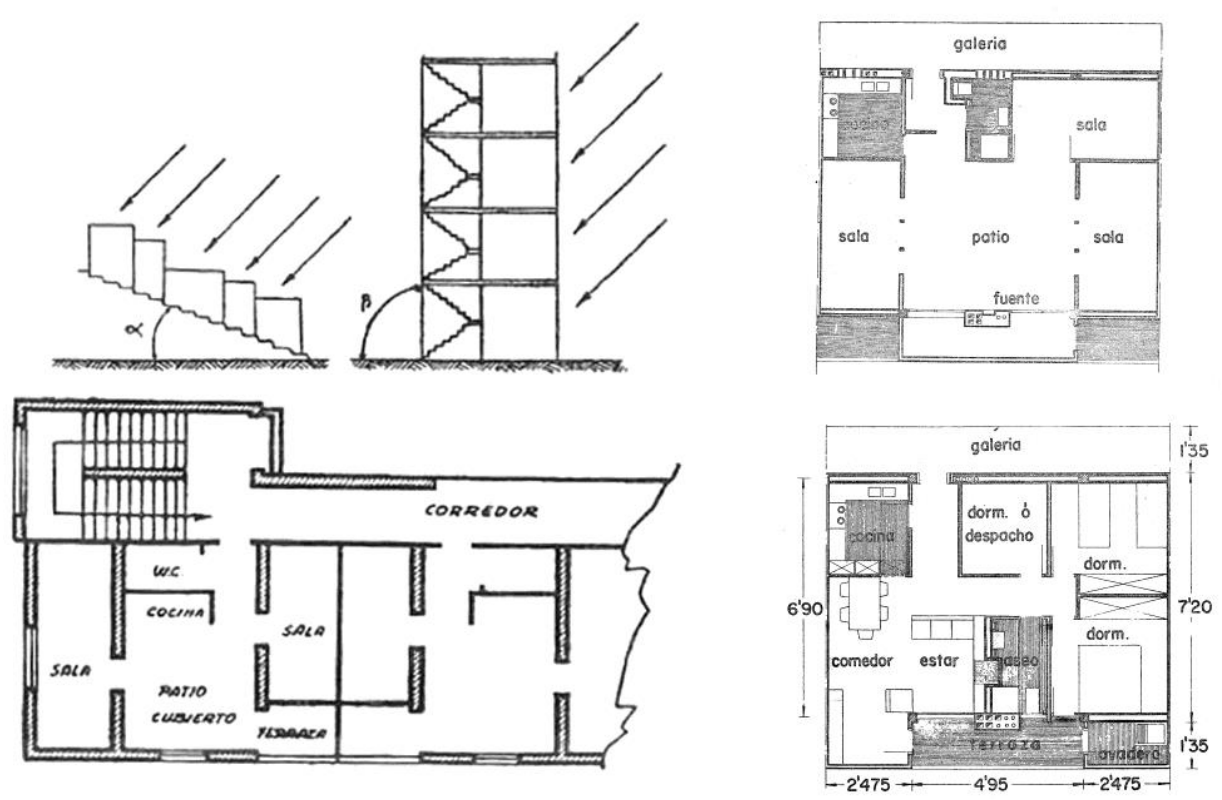

III. T2. Mulay Hassan housing slab. General scheme. Source: DE SIERRA OCHOA, A. (1960) La vivienda marroquí. Apuntes para una teoría. Ceuta: Editorial Cremades.

III. T3. Mulay Hassan housing slab. "Moroccan" and "European” apartment plans. Source: DE SIERRA OCHOA, A. (1960) La vivienda marroquí. Apuntes para una teoría. Ceuta: Editorial Cremades.

The version for Spanish settlers is a conventional 3 bedroom apartment, which enjoyed exterior views and had a terrace. The version for Moroccan natives greatly differs. It is, according to Sierra's, studies an interpretation of the traditional Tetouan patio house. A central open space takes on the role of the patio, with three chambers on each of its sides, plus a fountain space on the side of the façade, which remains closed off to the exterior. Following Sierra's schemes, the housing slabs were an analogy of the medina, but placed vertically, very much like ATBAT's Carrières Centrales in Casablanca. ${ }^{4}$

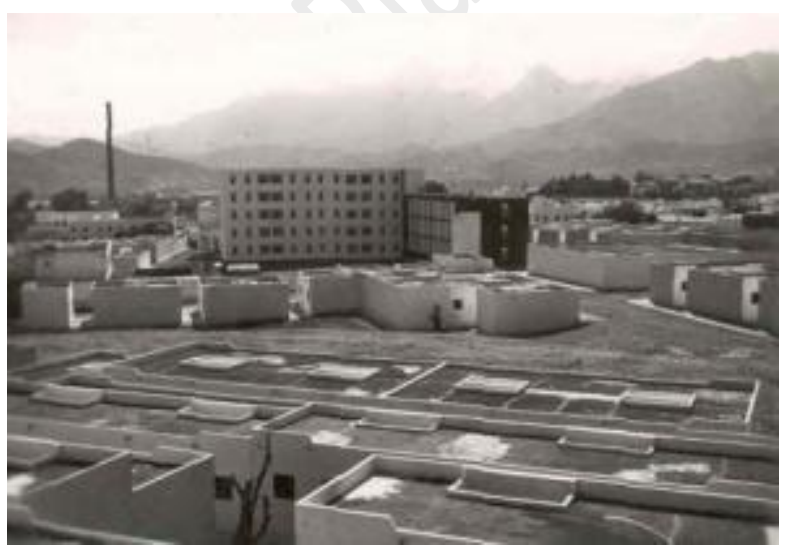

III. T4 General view of Mulay Hassan. Tetouan 1956. Source: FASO Fondo Alfonso De Sierra Ochoa. Biblioteca Vicente Aleixandre, Instituto Cervantes de Tetuán, Marruecos.

4 FONDO ALFONSO DE SIERRA OCHOA (FASO). In Biblioteca Vicente Aleixandre, Instituto Cervantes de Tetuán. Caja 5. Inventario de proyectos de vivienda de promoción pública de Tetuán. 
Interestingly, the original layout of the single family houses has been completely transformed. Additions to the houses have been made over time using reinforced concrete structures, which reach up to 3 and 4 additional storeys. On the other hand, the housing slabs remain relatively intact and in good condition-at least on its outside appearance, because our team did not ask for permission to enter the apartments, so as not to create false expectations among its dwellers. This leads us to the following question: were those homes adequate enough to begin with, or is it that they are simply impossible to transform?

\section{WESTERN SAHARA AND SIDI IFNI: A LATE COLONIZATION ISSUE, STILL UNSOLVED}

The history of Western Sahara and Sidi Ifni still remains controversial. Both territories were part of the ancient Sultanate of Morocco, which reached as far south as the Niger River. They became part of the Spanish protectorate in the Treaty of Fes 1912, but due to its arid climate, they were not effectively occupied until 1938. Both territories received their own administrative structure in 1946, becoming the Spanish provinces of Ifni and Spanish Sahara in 1958, as an act of nationalistic affirmation from Franco's Regime after the end of control over the Protectorate in the North of Morocco. They were always heavily disputed territories between Spain, Morocco, Algeria and the local Saharan population, a dispute that remains unresolved to our day.

The Spanish population settled in pre-existing towns such as Sidi Ifni, Dakhla (formerly known as Villa Cisneros) and El Aaiun. Before the arrival of the civil population, these towns were first occupied as military outposts and received the first industrial workers that arrived from Spain in 1947, after phosphates reserves were discovered at Bou Craa. These workers settled in temporary camps near the phosphate mines, which are the territory's main economic resource. The local Sahrawi population is of nomadic origin, and their ways of life were extensively studied by the Spanish anthropologist Julio Caro Baroja. The distribution of population throughout the land is not homogeneous and their traits differ greatly, with the Erquibat to the East, and the Tecna, UladTindrarit and Arosien on the Northern coast, and the Ulad Delin along the south coast.

Changes in traditional ways of life were brutal after the colonization process began. The Sahrawi population was first disarmed, then registered in the Spanish census, and then forced to settle. This last change had deep cultural implications, and was imposed for political reasons that had little to do with the actual needs of the population. Especially after Sahara became a Spanish province in 1958, international pressure led the Franco Government to respond with the construction of new settlements close to the existing towns, thus providing a new urban character that was previously non-existent in the country (RABASCO, 2013). 
Originally a military outpost, El Aaiun was chosen to become the capital of the Spanish Sahara due to the presence of water and the proximity of the coast. Original urban planning from 1940 to 1946 was pragmatic, and consisted of a simple grid, with the Plaza África, where the Spanish church stood, as the core of the town. This plaza also served as the separation between the civil area and the military area. The first comprehensive modern urban plan, in accordance with other settlement policies carried out during the last years of the colonial period, was designed in 1962 by Spanish architect Ramón Estalella, with Pedro Capote and Serrano Suñer as collaborators. This plan is a good example of how Spanish modern architecture equalled its European contemporaries, as well as a showpiece of the experimental character of colonial urbanism.
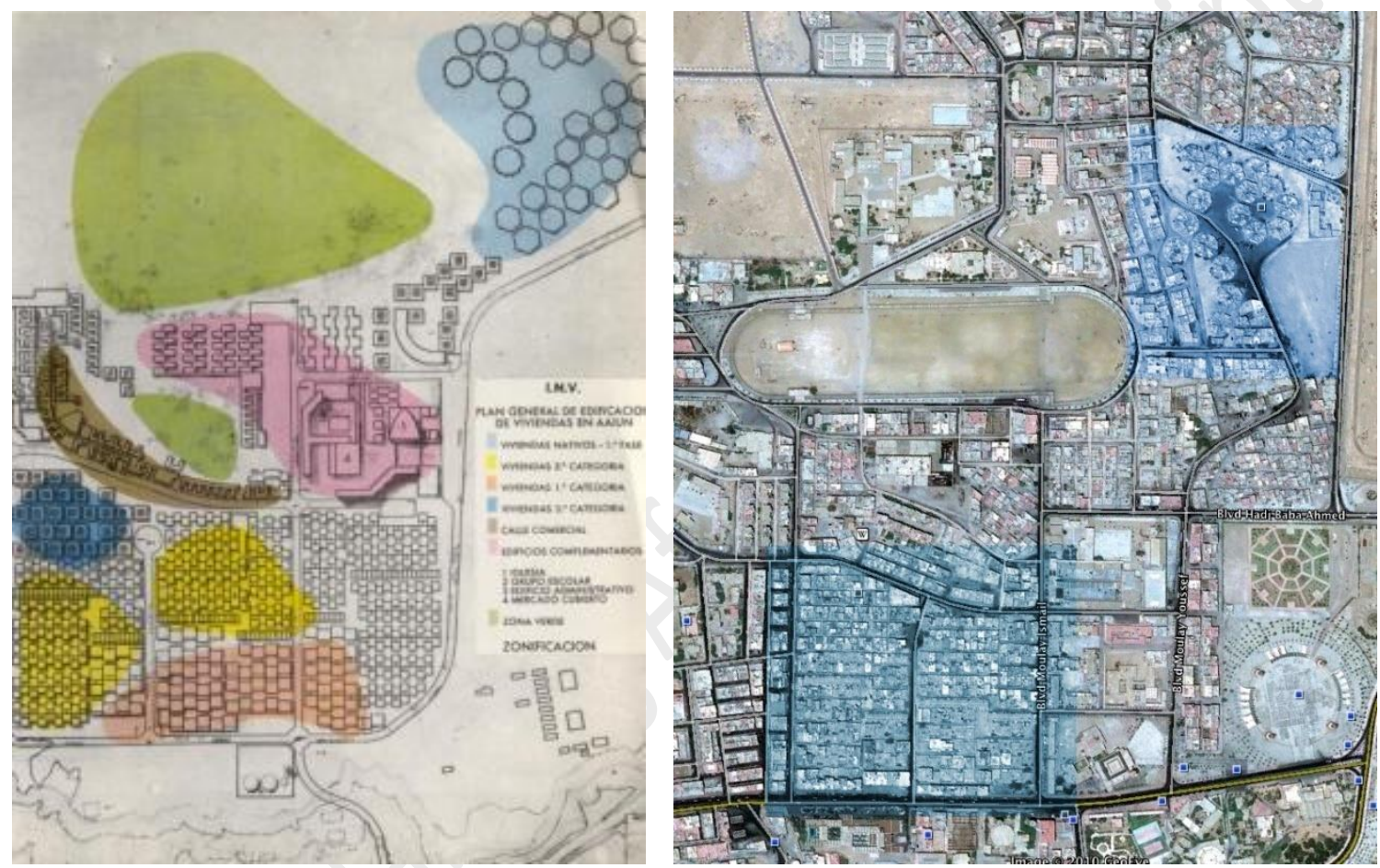

III. S1. Plan for El Aaiun, 1962. Ramón Estalella, Pedro Capote and Serrano Suñer. Source: Estalella R. "Viviendas en África”. Ed. Instituto Nacional de la Vivienda, Madrid, 1966.

III. S2. Aerial photograph showing (in blue) the interventions done by Ramón Estalella, Pedro Capote and Serrano Suñer in El Aaiun. Source: GAMUC Research Team.

Estalella's plan was intended to be built in different phases, and consisted of a new town for civilians to the South of the original Spanish military outpost. It intervened on three different levels, creating the core of the new town, with a church, a school, an administrative building and a market. From this area, a new commercial street led to the main access to the city from the East.

The last stage of this plan was the development of the residential areas, which reflected the politics of segregation that the Spanish government carried out between the settlers, who were placed to the North of the city's core, and the local population, who were located to the South of it. 
Estalella's housing scheme was distributed in four different areas; three to the north (of which only two were built) for the Spanish settlers, and one to the south for the local population. This comprised five different housing typologies; three for the Spanish settlers and two for the local population. Housing for Spanish settlers was intended to reflect the social organization of the colony. They were basically single family homes, each with an open patio, a convenient feature due to the local arid climate. However the houses were not solely of an introverted nature, they also provided a degree of openness towards the exterior. The houses differed only in size, which depended on the income level of their inhabitants. Their layout was based on the subtle use of a zigzag composition, the result of which created a picturesque effect of enclosure.

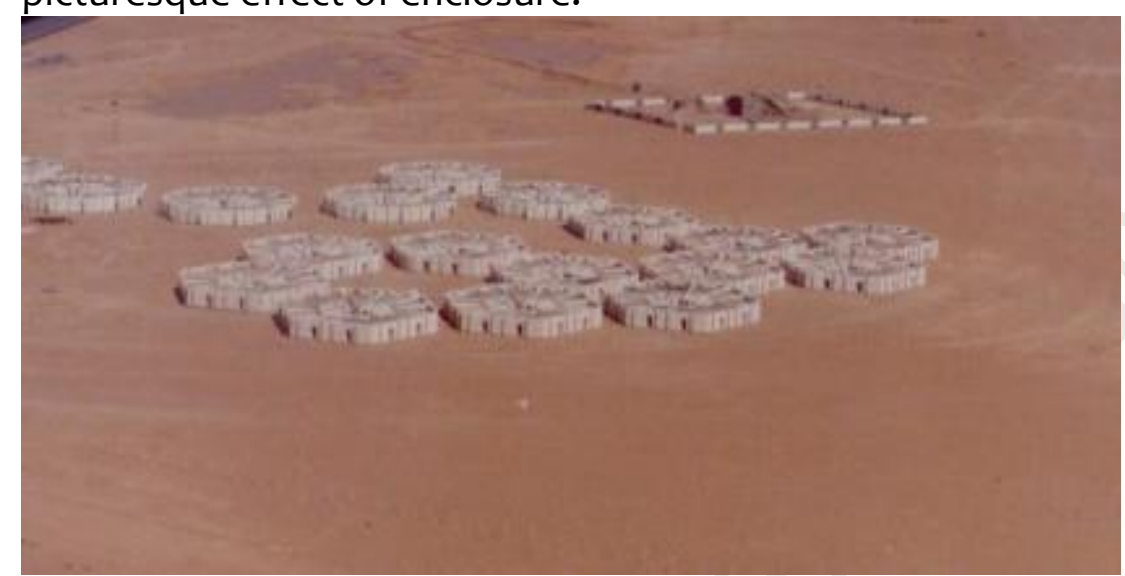

III. S3. Aerial view of the housing for natives in El Aaiun. Source: Ramón Estalella's personal archives.

There is an interesting approach to the design of the two typologies used for settling the local population. 18 compounds ( 216 houses) were built next to the airport, and another 5 (60 houses) additional units which were built at a second stage in 1965, next to the original military outpost in the North, along with a market. The layout of these units is based entirely on an introverted model, purposely adapted to the culture of the local population. Following the principles of modern movement urbanism, there are no streets, just an association of housing units that define the traits of the landscape due to the powerful shapes of their layout: spirals and hexagons.

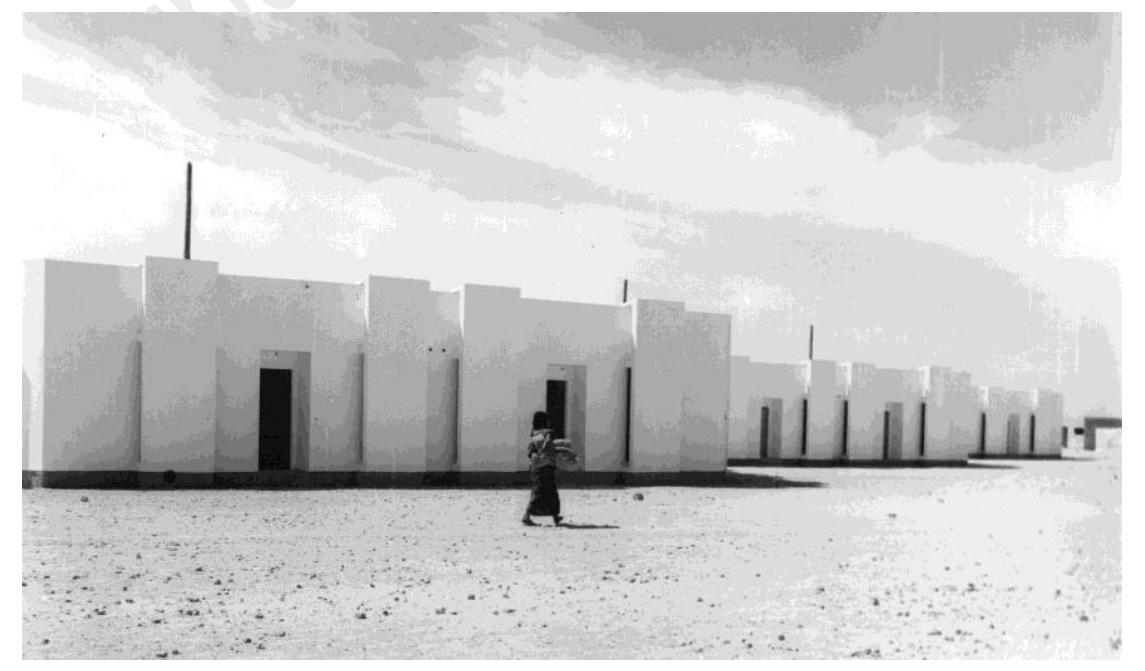


The spiral version comprised 12 houses per unit, grouped around a communal patio at the centre, enabling the dwellers to gather their cattle (mainly camels and goats) in that space during the night. The surface area of houses within the units was around $35 \mathrm{~m}^{2}$, each with a private patio of its own and access to the roof. The housing typology seems to be a curious interpretation of some of the "supposed" invariant features that had historically prevailed in the typical home of the Maghreb, such as the indirect access into the home or the use of lattice in the façade in order to avoid direct visual interference from the exterior. The hexagonal version comprised 6 housing units, which were larger in surface area but also shared the common patio scheme, as well as the mentioned typological devices.

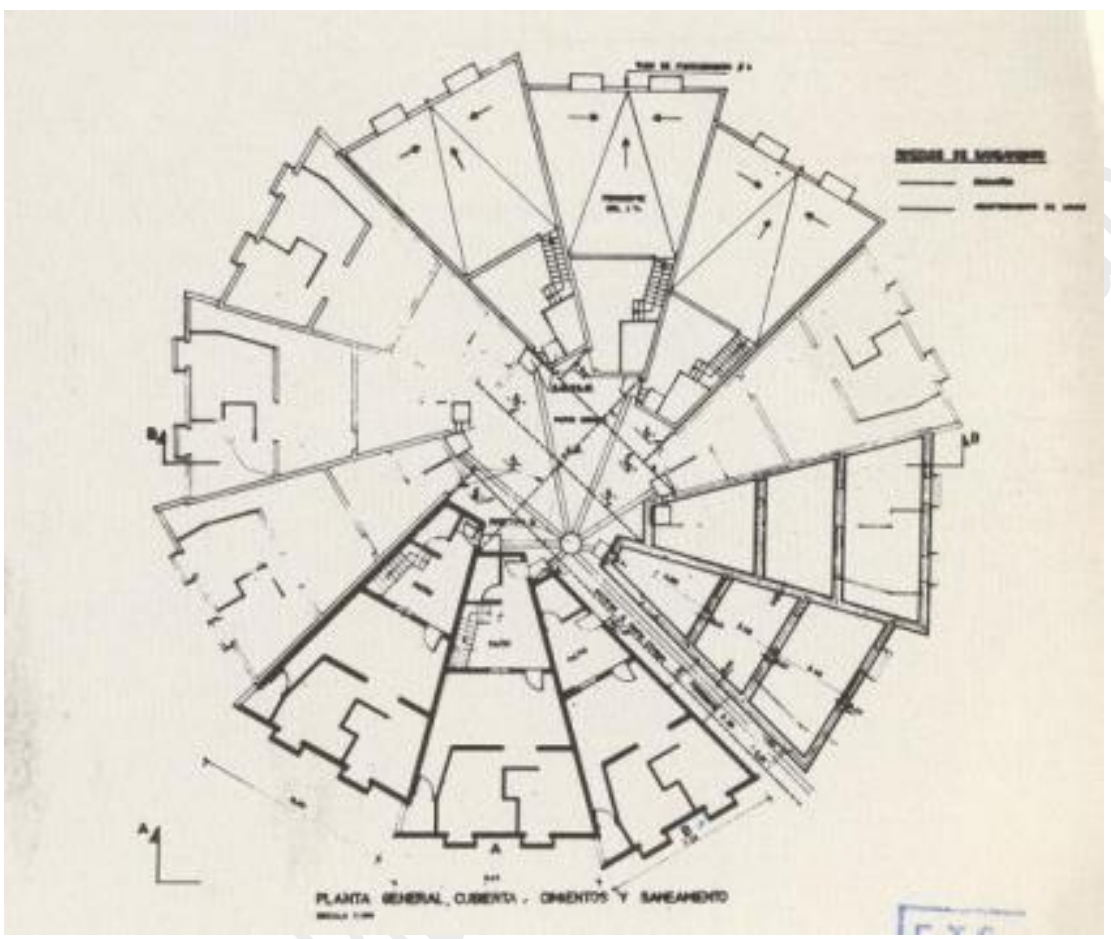

III. S5. Housing for natives in El Aaiun. Plan of the housing units. Source: Ramón Estalella’s personal archives.

\section{EQUATORIAL GUINEA: THE FORGOTTEN COLONY.}

The first 'owners' of the present Equatoguinean territories were the Portuguese, who discovered the island of Bioko in 1473 but did not establish a colony. Spain acquired ownership of the island in $1778^{5}$, which was named after the Portuguese explorer Fernando Po, a denomination that was used until the end of colonialism. Nevertheless, the first to establish a city on the island of Bioko were the British in 1827.6

\footnotetext{
5 Treaty of El Pardo between Da Maria I of Portugal and Carlos III of Spain. Portugal gave to Spain the islands of Fernando Poo and Annobon as exchange for the Santa Catalina Island and Sacramento territories in South America.

$6 \quad$ The island was named Bioko in 1979, by the Government of Obiang Nguema. First Portuguese discoveries in 1472 first called it in Formosa. But rapidly changed the name to Fernando Poo after the discoverer.
} 
Bioko was a key location to control slave trade and access to the core of Africa through the Niger River. ${ }^{7}$ During British occupation, Bioko became a strategic enclave of more importance than Freetown (Sierra Leone) itself, until Spain took over control of the island in 1843. Equatorial Guinea had more economic potential than Western Sahara, with more diverse raw materials and higher exports (Rio Juan, 1915). ${ }^{8}$ The Treaty of Paris in 1900 granted Spain the African coast between Campo and Muni. This territory and the island of Bioko together made up the country of Equatorial Guinea. Equatorial Guinea was declared a province of Spain in 1959, established as an autonomous region in 1963, and granted effective independence on October 12, 1968.

A keystone in the history of modern colonization in Equatorial Guinea was the establishment of the "Patronato de Indígenas" in 1904. This institution was in charge of monitoring the African population from a social, educational and judicial point of view. Black people did not have the legal status of adults so, according to the Spanish colonial government, this tutelage was needed. For example, a Decree in 1928 established the limit to land ownership by the Black population at a maximum of 4 hectares. 9

Unlike Morocco, where the power of Spanish religious congregations was not relevant, Claretian missionaries had a decisive role in the colonial enterprise in Equatorial Guinea (USERA, 1848), where the Catholic religion became even more influential than in Spain. The Claretians work fell in line with general colonial strategies, which followed two main premises: to conquer and to civilize. Their main goal was to create a new identity for the Equatoguinean people, who were considered to lack any sort of cultural personality, through a mixed program that combined religion, labour and the creation of a new lifestyle.

\section{Clarence City - Santa Isabel - Malabo}

The origins of Malabo can be traced back to Clarence City, founded by the British on a natural harbour, the Venus Bay, in an area with good topographical conditions. It was named after the Duke of Clarence and established in an area with no acknowledged pre-settlers, only 43 kilometres away from Victoria, Cameroon. Lead by Captain William Fitzwilliam Owen, the British established a new community of 402 people integrated by Europeans and liberated slaves from Sierra Leone, Liberia, Sao Tomé and other African nations. This combination of different cultural backgrounds was the origin of a new Creole society-made up of a population known as Fernandinos ${ }^{10}$ — that would develop fully during the $20^{\text {th }}$ Century. In 1950

\footnotetext{
$7 \quad$ The Roval Gazette \& Sierra Leone Advertiser, no 220, August 17, 1822

Rio Juan, Don Francisco. Atlas Icono-Geográfico-Estadístico del África Occidental Española, 1915 GOBIERNO GENERAL DE LOS TERRITORIOS ESPAÑOLES DEL GOLFO DE GUINEA, Memoria de la labor realizada en el periodo 1949-1955. Madrid, 1955

$10 \quad$ Holman, James. Travels in Madeira, Sierra Leone, Teneriffe, St. Jago, Cape Coast, Fernando Po, Prices Islands, etc, etc.; London, 1840. - According to Holman and other chronicles, the bubis were initially called fernandinos, as they were the people living in the island of Fernando Poo. But later, this denomination was extended to the new creole culture of the island.
} 
it is estimated that Bioko was inhabited by 3.080 Fernandinos (Liniger-Goumaz, 1988).

The market was the first institution in Clarence City, as a place of exchange between the Bubis ${ }^{11}$ and the British colonizers. It was an ephemeral space located approximately where Independence Square stands today. This space, which was inaugurated in 1827, was located on the axis of the bay, ${ }^{12}$ and from it the first urban plan of the city germinated. Conceived by British Governor John Beecroft and based on sanitary and hygienic criteria, the layout of this grid was based on the previous experience of the establishment of Freetown.

This first urban grid was limited by the present streets of Avenida 3 de Agosto, Avenida de la Independencia, Calle Rey Malabo and it is called Ensanche Fernandino. This area was initially populated by Fernandinos, (with an estimated population of 600 Africans and 100 Europeans in 1829) and later consolidated by Spanish settlers from the end of the 19th Century into the first decades of the 20th. In 1843 an expedition lead by Don Juan José de Lerena landed on the coasts of Clarence and changed the name of the city to Santa Isabel de Fernando Poo (after the Spanish Queen Isabel II), becoming the capital of the so called Spanish Territories in the Gulf of Guinea, and later the capital of the insular province of Fernando Poo (Bioko). Vicente Obama describes how, until 1916, the population settled in the old town, as well as in the Fernandine and Spanish "Ensanches" (Ondo Ada, 1982). But from 1920 onwards, given a faster growth of the economy, the first urban expansions occurred. Plots were enlarged, bringing about the mix of agricultural uses (some of the lots were originally used as orchards) with commercial and administrative uses, in 1 to 3-storey buildings, built using concrete structures. From 1950 to 1968, the periphery of Malabo boomed, and this urban development included residential neighborhoods such as Los Ángeles and Cocoteros.

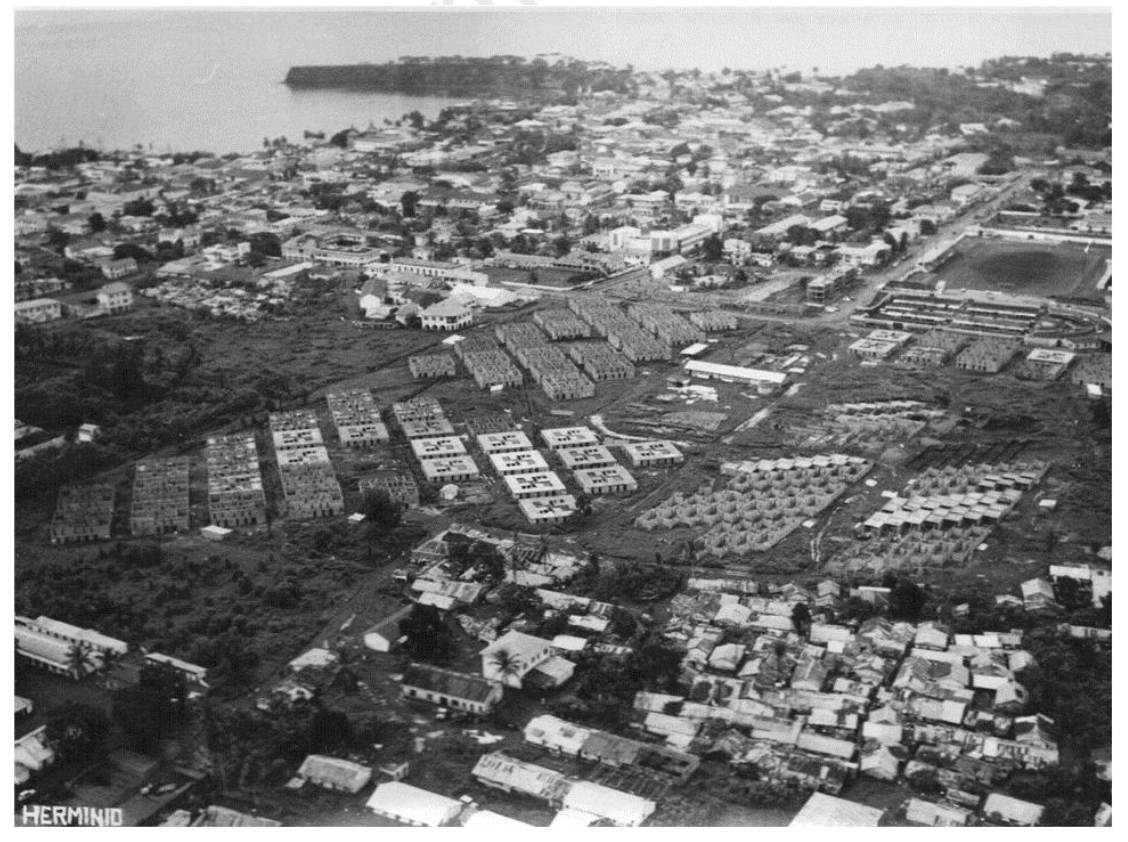

11 The Bubis are one of the indigenous inhabitants groups of the island of Bioko.

12 Informe de la comisión nombrada por el gobernador de Fernando Póo, May, 1861. Pag. 11. 
III. G1. Aerial view of Malabo, with Los Ángeles neighborhood in the foreground during construction, 1964. Source: Ramon Estalella's personal archives.

Both are first rate examples of the housing policies implemented during the period of political autonomy. Los Ángeles was intended to house middle income families, while Cocoteros adopted a higher end profile, destined mainly to house ministry advisors of the Autonomous Government. This period also included the construction of the "Poblados modelo" (Model Towns) implemented both on the island and the continental area. Construction activity during these decades contrasts with what happened shortly after Equatorial Guinea gained independence, when the building sector suffered a 10 year period of decline.

\section{Los Ángeles}

The Instituto Nacional de la Vivienda (Spanish National Institute of Housing) was created in 1939. It was in charge of developing public housing programs in Spain, as well as making sure these homes were adequately put to use. The Institute had its own legal status and was an autonomous administrative body; as such it was free to manage its properties. In 1957 the Ministerio de la Vivienda (Ministry of Housing) was created, and the Institute was incorporated into the Ministry.

A Development Plan for Equatorial Guinea was designed to take place spanning from 1964 to 1967. It was led by Don Juan Alvarez Corugedo, ${ }^{13}$ who wrote about it for Revista África in 1967. On one hand, the main goal of the Plan was to improve basic public services, while at the same time, to coordinate investment in public works, health, education and housing. On the other hand, the plan intended to stimulate the private productive sectors. The budget for this Project came from the Spanish Government, as well as from local resources in Equatorial Guinea. Specifically, the housing projects and their implementation were to be financed through funds from the Spanish government budget.

The housing program was meant to span three years. It included urban interventions in the two provinces, Rio Muni and Fernando Poo. One of the most significant interventions was the construction of the Los Angeles neighborhood. It included 759 housing units in an area known as Campo Yaunde, to consolidate the existing urban layout inhabited by immigrants of mostly Nigerian and Cameroonian origin.

Ramón Estalella, who had previous experience working in Western Sahara, was the leader of the group that designed the neighborhood. The team was integrated by Alberto Ripoll and Ignacio Prieto, while Fernando Tobileri Melelo took on the role of building engineer. ${ }^{14}$ Estalella's approach to housing design, at least on paper, showed empathy with the living conditions of the local population. The design of the homes was meant to adapt to the rainy climate, while protection from the sun

$13 \quad A B C$, September $27^{\text {th }} 1964$, page 93

14 Interview with Ignacio Prieto, January 2011; BOE núm. 77, March 31, 1966, page 3807 
in the urban layout was entrusted to the shade cast by the massive native Egombegombe trees. But as what usually happened with Spanish architects, this knowledge was greatly based on stereotypes, and was strongly tied to their role as actors of the colonial enterprise.

The general layout of Los Angeles depicts the shape of a fan, leaving a central space for public facilities. Around this space, four main housing clusters are organized. Three of them show the square housing block called duplex "cuadrado", 63 in number, with 8 housing units each. Duplex "cuadrado" includes the A and B typologies with 2 level houses, and incorporated a private patio at the centre of the block for ventilation purposes.

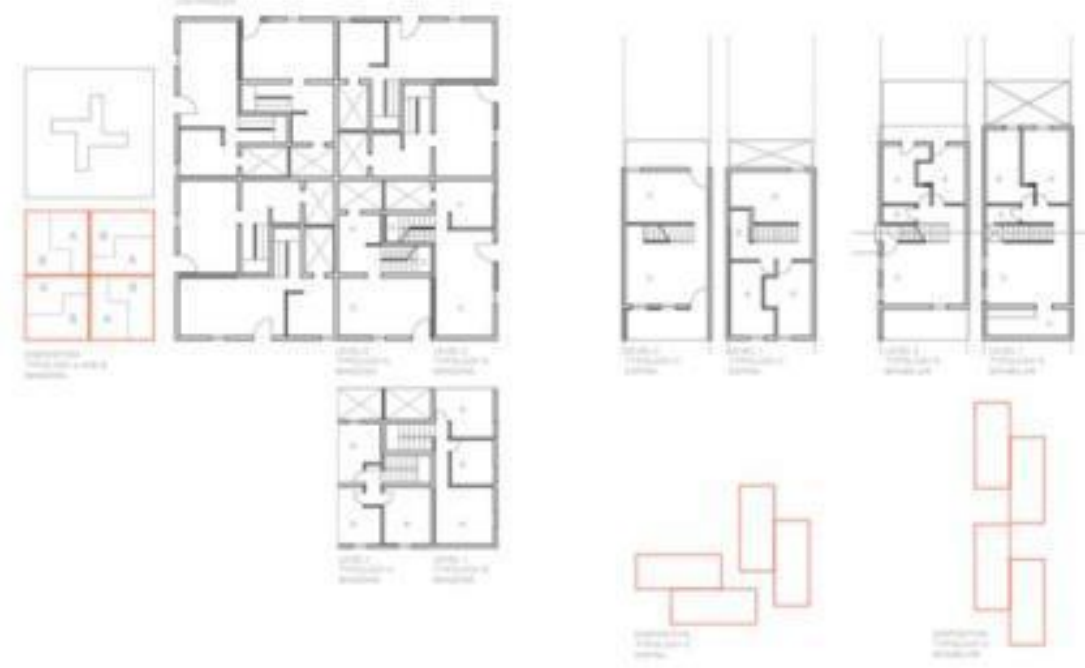

III. G2. Los Ángeles neighborhood, Malabo. Plans of the housing units. Source: GAMUC Research Team.

Two other housing typologies were implemented, known as bifamiliar, including the $C$ and $D$ typologies. $C$ follows a fish spine layout, and its plan is similar to that of the $A$ and $B$ typologies, organized on two floors. The $D$ type included two different houses, one for single people at the ground level, and another for families in the first floor.

The layout of the buildings intended to create spatial variety and to become a camouflaged pattern once the greenery was planted in the interstitial triangular spaces between the housing units and the streets. Public spaces have been occupied, in some cases, by the inhabitants of the bigger duplex "cuadrado" units. During our fieldwork visit to the area we found that some of the dwellers of the $A$ and $B$ typologies had occupied the street at the entrance of their homes with improvised kitchens and other furniture. 


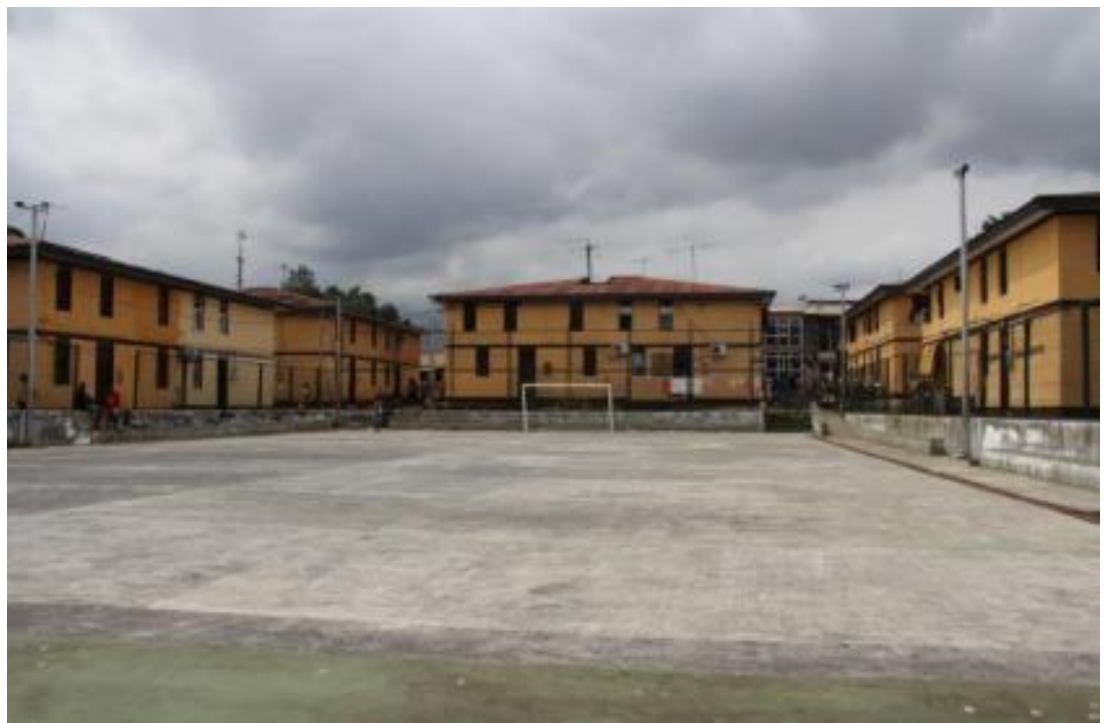

III. G3. Los Ángeles neighborhood, Malabo. Central sports area. Source: GAMUC Research Team

Nevertheless, the spatial richness of the compound remains in good condition. This may be due to the strict building code that the government established after Independence, which prohibited any unauthorized transformation of the houses. The shade produced by the displacement of the upper floor with respect to the ground floor in the $C$ and $D$ typologies creates an intimate space that allows domestic life to extend from within the house to the outdoors. Moreover, the homes for "singles" in typology D have mutated into small shops that have created openings in the façade to enable a public access.

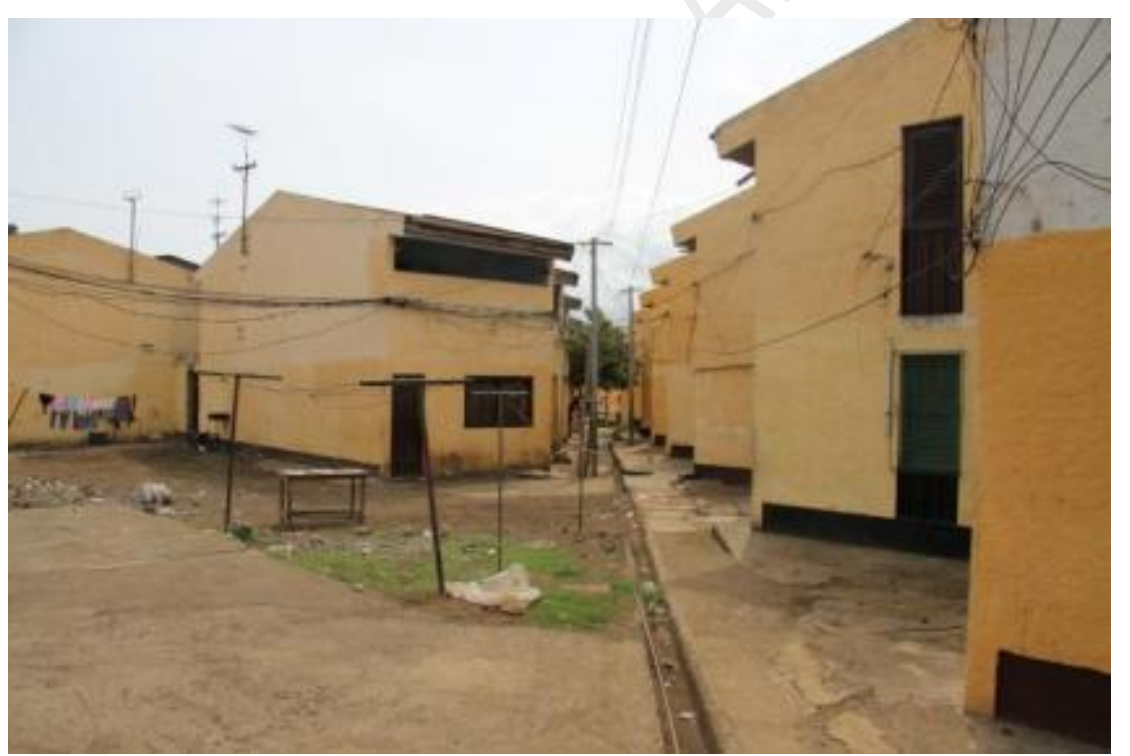

III. G4. Los Ángeles neighborhood, Malabo. "C" and “D” typologies. Source: GAMUC Research Team

The spaces in direct relation to the houses, the inner streets, the quadrants' squares and the main plaza were intended to create several degrees of public life. Through our onsite research we have noticed that public space has been only mildly transformed, adapting itself to the different social contexts of the 45 years since political independence of Equatorial Guinea. However, we may also consider that 
this is probably due to the limited economic resources of the population, a fact that prevents any kind of radical alteration.

\section{THEORETICAL NOTIONS ON HISPANIC AFRICA: COLONIALISM AND SPATIAL TRANSFORMATION}

The history of European colonialism in Africa in the $20^{\text {th }}$ century goes hand in hand with the development of modern architecture and urbanism. To a certain extent, architectural modernism was a perfect strategy that succeeded in imposing spaces and urban forms, but did not manage its intended social transformation. Modernism was based on a discourse of social concern, but as well as the discourses on the development of the Corporate States in Africa, it shared the same contradictions.

Experience shows the failures in the discourse of modernism despite the fact that it was highly attractive for the cultural elites and purposely flexible for some political elites. Furthermore, the breakdown of modern architecture coincided with the period of the widest proliferation of its projects as well as with its utmost international expansion. But we could state that these coetaneous processes of expansion and dissolution of the modern movement did not mean decadence at all, rather on the contrary, they made the production process of buildings and neighbourhoods extremely significant in order to understand the present state of former Spanish African colonies.

Social and political regulations which were inherent to colonial urbanism and the production of social housing provided a new spatial model to the population, for both natives and foreign settlers. But at the same time, they also brought about a decision-making system in which future dwellers were excluded from participating in the design and construction of the space they were to live in. As Laroui states: "The search on the social and ideological roots of the Moroccan nationalist movement, leads to: westernization, modernization, politicization, and nationalization" (2001, p.17). This had two main consequences:

- Forms of local pre-colonial production of space, present in the Arab-Moroccan medinas, the Rif-Moroccan dowares, the Sahrawi Kasbahs, or the Fang villages in Equatorial Guinea, stopped evolving and were left frozen in time. Meanwhile their constitution and elements were interpreted in banal ways by the colonizers.

- The usual practice of self-built construction on the outskirts of cities was immediately excluded from the legal realm, and the inhabitants of these informal areas were stigmatized at a social level.

The urban and architectural designs of Alfonso de Sierra Ochoa and Ramón Estalella show how the population was relinquished in its power to choose, despite the effort of both architects to bring up the issue of the reinterpretation of the local habitat, and their explicit "intentions" of not wanting to impose new ways of life, especially on the local population. Theirs can be considered a meaningful attempt 
because of their proximity to real needs, if we compare their experiences with those of the French, English or German colonization. But the final result was, nevertheless, a narrowing down of reality to the constraints of their interpretation as architects and that of the colonial authorities.

The example of Tetouan and its periphery also shows that this issue did not only apply to the local Moroccan population, but acquired a social dimension. The housing reality was so complex that as it was determined by matters of class, further dividing the dominant Spanish-Moroccan class and Spanish-Moroccan excluded class. ${ }^{15}$.

\section{An insight into the matter of appropriation}

The main historical narrative of modernization also has its own marginal features, contradictions and exceptions, which constitute what historical coherence calls "otherness". Nevertheless, if human beings and human communities are the main actors of this historical narrative, they will never understand their own cultural construction as being "marginal", as they claim that their role is a leading and active one. As Bourdieu says, everyday life blurs the margins, making them invisible from the inside, establishing a relational evaluation of facts (BORDIEU, 2009).

Reality, as it is observed from the point of view of a "marginal" inhabitant, can never be at the sidelines, as it constitutes the inhabitant's point of reference, and the center of his experience. It is the foreigner, the one who does not belong, who places the center elsewhere. That is why Bourdieu insists, that "meanings" should be left aside, as everything is relational to the place that constitutes the center of individual human experience.

These considerations on multiplicity, recalling Gilles Deleuze's "milles plateaux", acknowledge production of housing and the management of the city as an imposing act of power. This imposition uses imported means to define habitats and urban environments: property, the distribution of urban wealth, zoning prescriptions, typologies and technology. But besides the main agents of power, the other relevant players in the city, including the different social classes, the local authorities, the native population as well as the new settlers, also found their way to fit into this new urban realm.

Thereby, the urban periphery becomes an expression of diversity and multiplicity, from which official discourses (colonial, modern, western or local) are challenged by the uses of everyday life and the participation of the population-with no exceptions, from the excluded classes to the dominant elite- in the production of the city and the urban habitat. The examples of public housing that have been described here were themselves at the periphery of "official" thinking, as radical expressions of the dominant ideology that built the urban centres of colonial cities.

\footnotetext{
15 Studies made by Alejandro Muchada about Tetouan's outskirts in tetouanmodernchallenge.com. Interviews with neighbors from the "Málaga" social housing neighborhood in Tetouan. http://player.vimeo.com/video/32838044
} 
These housing projects were located in the urban periphery of colonial cities with the intention of being symbolic examples of "order" and "progress". The previous existing context was normally that of self-built neighbourhoods, which were originally the result of the autonomous initiative of the excluded urban population. Despite the precarious living conditions in these neighbourhoods, these areas revealed just how capable their inhabitants were of confronting and solving their basic daily requirements, and how they managed to meet their needs within the rules of the existing power structure.

The supposedly "Moroccan house" of Mulay Hassan, the presumably "Sahrawi house" of El Aaiun or the seemingly "Equatoguinean house" of Los Angeles did not actually exist, because, in fact, there never were any real models to follow. Depending on the condition of class, ethnicity, or even the gender of the family leader, among other factors, there were different "milles plateaux", "milles logements", and a multiplicity of solutions which could have suited the real needs of the population. However, this was never openly acknowledged, and colonial governments imposed their version — very much as they did in Europe-of what people should aspire to. This constitutes a much greater contradiction in Africa, where these artificial goals were simply unattainable.

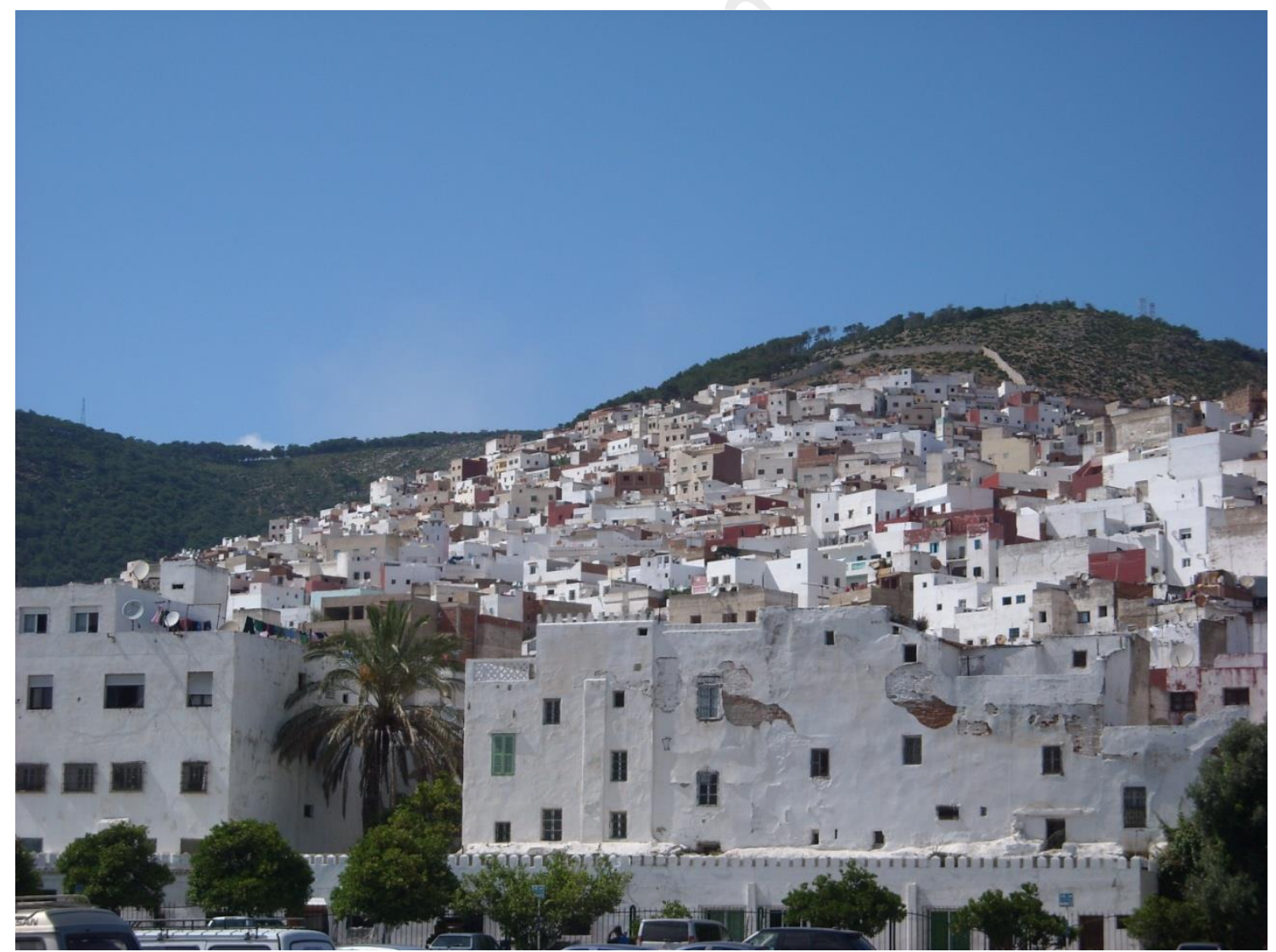

III. Popular sttetlement “Jbel Dersa”. Tétouan, Morocco (2011). APMS. Source: APMS Personal Archive Muchada Suárez. 
Social productivity became part of the political ideology in many African colonies, which meant the loss of the natural ways the local populations settled their territories. The relationship between traditional habitats with their cultural roots, as well as their usual ways of transformation and appropriation were violently obliterated by the paradigm of productivity. The shared spheres of the city were designed solely from the point of view of the colonizers, who, furthermore, believed in their role as merciful donors of civilization.

Any previous understanding of intimate and communal habitats was substituted by the global bureaucratic framework, which by no means was provisory: transformations had arrived to stay, and remained long after the end of colonization. As Mbembe points out, this institutionalization meant the "abolition of long distances, as well as the abolition of everyday life in remote environments" (Mbembe, 2008). Modernization thus meant the process by which quantity became essential. This would channel the path of history as a narration derived from the Western world, unifying human intervention on foreign concepts such as time and territory.

The less acquainted colonizers were with local realities, the riskier became the implementation of the Western theories that strived for their transformation, leading to even more audacious efforts in the continuous improvement of the imported narrative of modernization. In contrast to this, as Young says, we still should consider "the possibilities to theorize history anew, from a multiple, twisted and tensioned perspective, considering diverse narratives and times, which sometimes may not even be compatible at all" (2008, p.199).
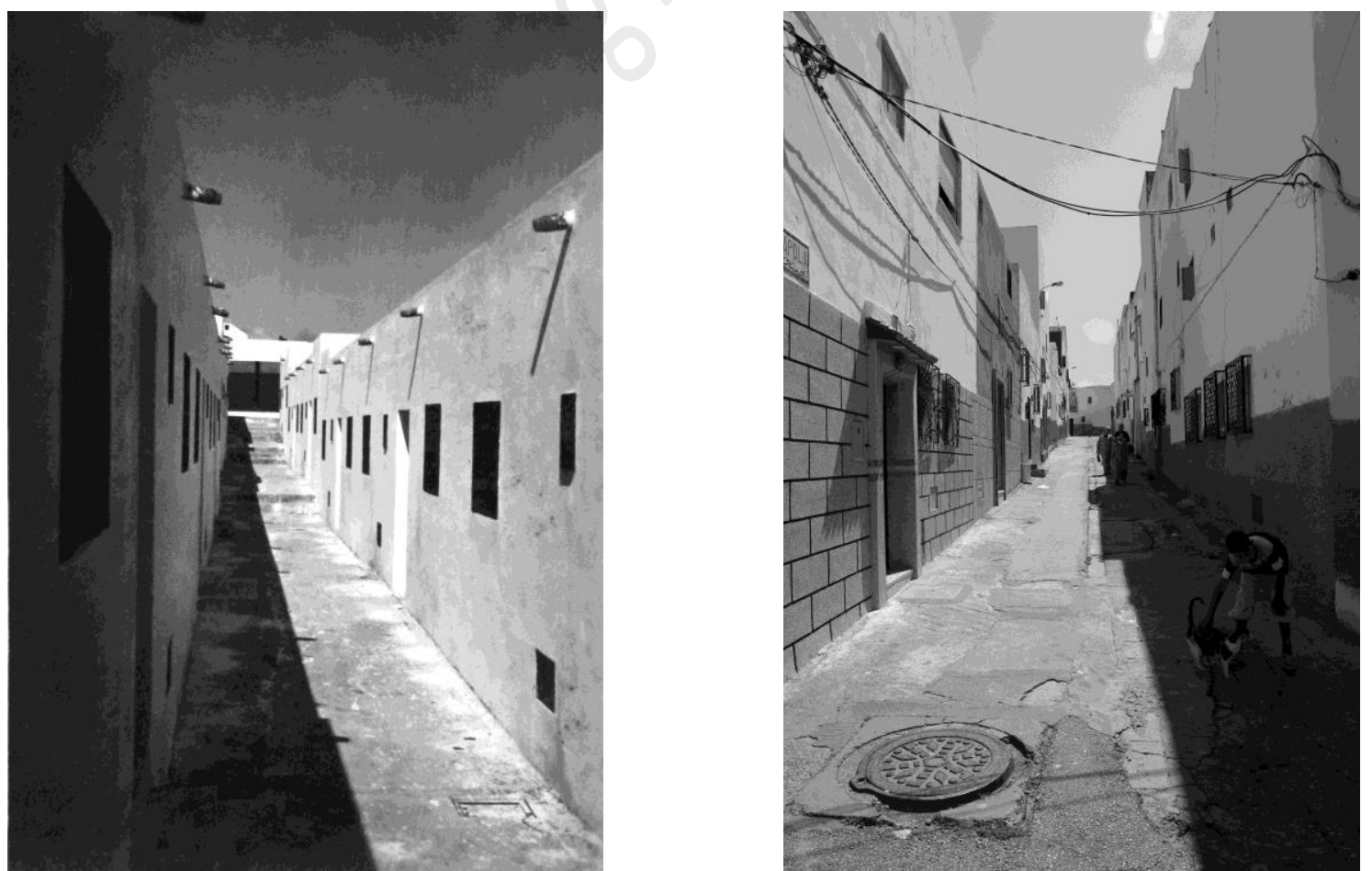

III. General view of Mulay Hassan. Tetouan 1956. Source: FASO Fondo Alfonso De Sierra Ochoa. Biblioteca Vicente Aleixandre, Instituto Cervantes de Tetuán, Marruecos.

III. General view of Mulay Hassan. Tetouan 2011. Source: APMS Personal Archive Muchada Suárez. 
Translated into the Spanish-African context, this offers the possibility of recognizing a diversity of habitat production strategies, especially those carried out by the local population. This is a phenomenon of extraordinary importance, which is boosting the urban expansion of Morocco, Western Sahara and Equatorial Guinea, while at the same time generating a complex articulation of the modernization of urban habitats. Its stigmatization by colonial powers, as well as by the new independent Governments, has meant a complete loss of self-understanding, and the negation of a whole variety of potential areas for real social progress.

Following the dualism between Imperialism and Empire, as Negri and Hardt have recently addressed in their work (Negri \& Hardt, 2002), we should come to terms with the fact that the current metropolis is to all of us what the factory was to the working class. Taking this statement as a starting point, we can deduce that there is an embryonic relationship between the different modes of territorial denaturalization that have affected the inhabitants of most former African colonies. This can be found both in the process of definition of habitat that was imposed in the mid $20^{\text {th }}$ century, as well as in the process of decolonization and redefinition of the modes of territorial control that emerged in the $1980 \mathrm{~s}$.

Similarly, the search for a new narrative should consider the disjunctive put forward by $G$. Spiyak about the description of the imperialist project through a Heideggerian dialectic between the World and the Earth (Spivak, 2010). This serves as a powerful tool, enabling a cartographic reconstruction of the constant aggression against the Earth carried out by the World, using the anonymous techniques of Capital (these being, among other, physiocracy, mercantilism, free market, or even the civilising mission), which perpetuates the assumption of the native as "the other". ${ }^{16}$

\section{CONCLUSION}

Spanish colonial action was decisive in the outlining of the contemporary processes of urban and territorial development in Morocco, Western Sahara and Equatorial Guinea, where the index of urban development was originally very low. Nowadays, urban development indexes in Morocco are overwhelming, due to recent economic development. The situation in the case of Western Sahara is constantly challenged by political and social unrest. This has lead to the emergence of extensive refugee camps around major cities as well as in the dessert and the promotion of a rapid urbanization process by the government of Morocco as tool of political pressure. Population growth in Equatorial Guinea is constant, leading to the creation of a landscape of slums whose social effects are worsened by the unfair distribution of wealth.

\footnotetext{
16 This is particularly important in the current context, where financial capitalism from Europe has renewed the colonial vision by inducing the formation of industrial production ghettos, which appeared firstly in the north of Africa. Nowadays, any place in Africa can be object of the production system through the maquilas (contracted factories) of any great transnational company.
} 
In this context, the housing question still remains unresolved. From the very origins of this urban modernization process during the colonial period, poor dwelling conditions as well as urban exclusion have been on a constant rise. Even if we allow ourselves to consider that the Spanish colonial social housing projects were closer to the real needs of the population than those carried by other colonial powers in Africa, and even though we may find them less intrusive in their implementation, their modern traits determined that reality was standardized, that the production of a urban habitat was unequal, and that the power of capitalism was the only influence in the decision making process of designing a the setting for everyday life. If we compare the ways of habitat production between what the colonial powers did in their day and what the independent governments of former Spanish African colonies are currently carrying out, we come to realize that the logic of the process has not changed. People are still excluded from the official definition of an "identity", as well as from the debate regarding in which ways public habitat programs can improve in their lives.

\section{BIBLIOGRAPHY}

BARTHEL, P; VERDEIL, E. (2009). « Experts embarqués dans le « tournant financier ». Des grands projets urbains au sud de la Méditerranée». Annales de la recherche urbaine, $n^{\circ} 104, p p .38-48$.

BORDIEU, P (2009). El sentido crítico. Mexico DF: Siglo XXI.

LAROUI, A. (2001) Les origines sociales et culturelles du nationalisme marocain (1830-1912). Rabat: Centre Culturel Arabe, p.55

LINIGER-GOUMAZ, M. (1988). Small is not always Beautiful. The Story of Equatorial Guinea, London: C. Hurst and Company, p.24

MBEMBE, A (2008). "Al borde del mundo. Fronteras, territorialidad y soberanía en África”, in MEZZARA, S. (ed.), Estudios Postcoloniales, Madrid: Traficantes de Sueños.

MUCHADA SUÁREZ, A. (2012a). Tetuán desafío moderno 1912-2012. Alfonso de Sierra Ochoa y la cuestión de la vivienda. Tetouan: Instituto Cervantes.

MUCHADA SUÁREZ, A. (2012b). "Notas para una teoría de la vivienda y la ciudad rifeña. De la ciudad-territorio a la megápolis mediterránea”, in Actas del Coloquio Internacional: Colloque Internationale Patrimoine culturel du Rif : quelle muséographie ?". Rabat, Casablanca. Conseil National des Droits de l'Homme de Marruecos (CNDH) ; Les Editions Le Croisée des Chemins. NEGRI, A.; HARDT, M. (2002) Imperio. Madrid: Paidós

ONDO ADA, V.O (1982). La ville de Malabo et les campagnes de l'ile de Bioko (Guinee Equatoriale). Toulouse Le Mirail : Université de Toulouse Le Mirail, RABASCO POZUELO, P. (2013) «Ciudad y vivienda experimental en Ifni y el Sáhara Español: una expresión de modernidad en los años 60». Ciudad y Territorio. Estudios Territoriales 178. Madrid: Ministerio de Fomento.

RIO JUAN, F. (1915). Atlas Icono-Geográfico-Estadístico del África Occidental Española. Madrid: Juan Pérez Torres.

SALAS LARRAZÁBAL, R. (1992) El protectorado de España en Marruecos. Madrid: MAPFRE, p.188 
SIERRA OCHOA, A. (1960a). La vivienda marroquí. Apuntes para una teoría. Ceuta: Editorial Cremades.

SIERRA OCHOA, A. (1960b). El plano de la ciudad de Tetuán. Madrid: Consejo Superior de Investigaciones Científicas e Instituto de Estudios Africanos.

SIERRA OCHOA, A. (1962). Urbanismo y vivienda en Tetuán. Conferencia pronunciada en el salón de actos del Consejo Superior de Investigaciones Científicas, el día 21 de marzo de 1962. Archivos del Instituto de Estudios Africanos. Año 16 n64 (Octubre 1962), p.75-100.

SOUAMI T., VERDEIL E., (2006), Concevoir et gérer les villes - Milieux d'urbanistes du sud de la Méditerranée. Paris : Economica, Anthropos, collection « Villes »

SPIVAK, G. (2010). Critica de la razón poscolonial. Hacia una historia del presente evanescente, Madrid: Akal.

USERA Y ALARCÓN, J.M. (1848). Memoria de la isla de Fernando Poo. Madrid.pp. 63, 67,73.

VILLANOVA VALERO, J. L. (2006) Los interventores. La piedra angular del Protectorado español en Marruecos. Barcelona: Bellaterra, p.180.

YOUNG, J.C. (2008), « Nuevo recorrido por las mitologías blancas », in MEZZARA, S. (ed.), Estudios Postcoloniales, Madrid: Traficantes de Sueños.

ZAKI, L. (2006) « L'action publique au bidonville: I'État entre gestion par le manque, "éradication" des kariens et accompagnement social des habitants ». L'année du Magreb - 2005-2006 Dossier : Femmes, famille et droit. Paris : CNRS Editions, pp. 303-320 